\title{
Photoaffinity labelling of hepatic plasma membranes suggests two classes of hepatic insulin receptor
}

\author{
F.J.Haynes and C.C. Yip \\ Department of Physiology and the Banting and Best Department of Medical Research, University of Toronto, Toronto, Ontario M5G 1L6, \\ Canada
}

\begin{abstract}
Summary. Photoaffinity labelling of hepatic insulin receptors revealed specifically-labelled bands of 130,90 and $40 \mathrm{kDa}$. Endogenous protease activity in hepatic plasma membranes, as well as contaminating proteases present in preparations of clostridial collagenase, degraded some of the $130-\mathrm{kDa}$ insulinbinding subunit to a $115-\mathrm{kDa}$ form. However, a large proportion of the $130-\mathrm{kDa}$ subunits were resistant to degradation, suggesting the presence of two classes of insulin receptor in hepatic plasma membranes. In one class the 130-kDa subunit was sensitive to proteolysis, while in the other it was not. In
\end{abstract}

contrast, the $130-\mathrm{kDa}$ receptor subunits of adipose tissue were all resistant to such degradation. Scatchard analysis of control and collagenase-treated plasma membranes demonstrated that conversion of the $130-\mathrm{kDa}$ subunit to a $115-\mathrm{kDa}$ form did not affect the insulin-binding characteristics of the receptor. It was also apparent that insulin binds to a single class of highaffinity sites in hepatic plasma membranes.

Key words: Insulin receptor, $\alpha$-subunit, insulin binding.
It is now well-established that the insulin receptor of several tissues, including liver, fat and human placenta, contains disulphide-linked glycoprotein subunits with respective molecular weights of 125-135 and 90-95 $\mathrm{kDa}$ [1-5]. The 125-135-kDa subunit is considered to be responsible for insulin binding [1-5] and the 90-95-kDa subunit has been characterised as a protein kinase [6]. A specifically-labelled band of $40-45 \mathrm{kDa}$ has also been detected by several laboratories [1-4]. However, disagreement regarding the significance of this component $[1,4,7]$ has resulted in two different models of the insulin receptor $[1,3,4,8]$. In one model the insulin receptor is suggested to exist as a heterodimer of $(\alpha \beta)_{2}$ [4]. In the other model the insulin receptor is suggested to contain components of $85 \mathrm{kDa}$ and $40 \mathrm{kDa}$ as well as the $\alpha$ and $\beta$ subunits [1,8]. In addition, a specifically-labelled band of $120-125 \mathrm{kDa}$ has been observed in the insulin receptor of hepatic tissue. Fehlmann et al. $[9,10]$ suggest that this is a degradation product of the $125-135-\mathrm{kDa}$ subunit, produced by endogenous protease activity [9] and by preparations of clostridial collagenase [10]. If so, this indicates that the $125-135-\mathrm{kDa}$ subunit present in hepatocytes and hepatic plasma membranes exists in a partially-degraded state. Alternatively, others have suggested that hepatic tissue contains more than one type of insulin receptor [11-14]. Thus, Donner and Yonkers
[14] concluded that the $120-125-\mathrm{kDa}$ subunit represents the high-affinity binding site for insulin. The nature and role of the $120-125-\mathrm{kDa}$ subunit in insulin binding therefore require further study.

We have used the technique of photoaffinity labelling to examine the relationship between the $125-135-\mathrm{kDa}$ subunit and the $120-125-\mathrm{kDa}$ band. The binding of insulin as influenced by the relative abundance of these two forms of subunit was analysed by Scatchard analysis.

\section{Materials and methods}

The preparation and characterization of the photoreactive derivative of insulin, $\mathrm{N}^{z \mathrm{~B} 29}$-monoazidobenzoyl insulin (B29-MABI) used in this study have been described previously [15]. The B29-MABI photoprobe was iodinated using chloramine $T$ [15] to a specific activity of $150 \mu \mathrm{Ci} / \mathrm{nmol}$. Bovine insulin was a gift from Connaught Laboratories Ltd (Canada). Type 1 clostridial collagenase $(130 \mathrm{U} / \mathrm{mg})$ was purchased from Worthington Diagnostic Systems Inc. (Freehold, New Jersey). Benzamidine was purchased from Aldrich Chemicals Co. Inc (Milwaukee, WI). Staphylococcus aureus V8 protease $(505 \mathrm{U} / \mathrm{mg}$ ) was purchased from Miles Scientific (Naperville, USA). Trypan Blue and all other enzymes and inhibitors were obtained from Sigma Chemicals Co. Inc. Leibovitz medium (L-15), Eagle's Minimum Essential Medium (Eagle's medium), penicillin, streptomycin, fetal calf serum and fungizone were purchased from GIBCO (Canada). Mono- 


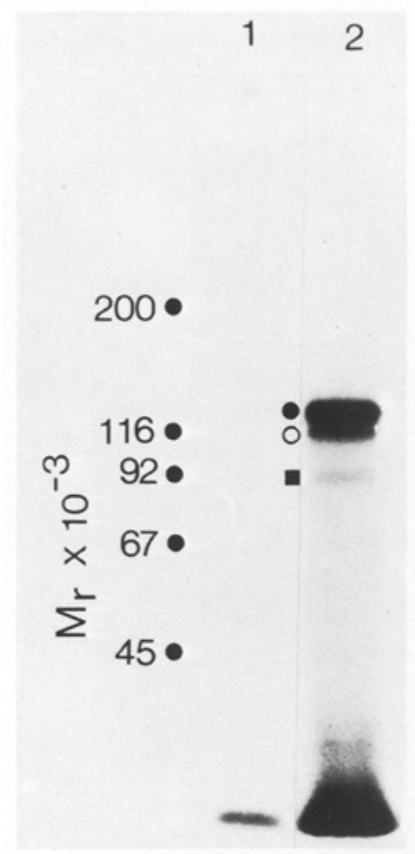

Fig. 1. Radioautogram showing specific labelling of subunits in the hepatocyte insulin receptor. Freshly-isolated hepatocytes were obtained by digestion with clostridial collagenase and then photolabelled and analysed by electrophoresis as described in the text. Lane 1 was obtained from cells incubated with photoprobe in the presence of excess insulin. Dots indicate the position of protein standards used to calculate apparent molecular weights. The specifically labeled bands of $130 \mathrm{kDa}(\mathbf{O}), 115 \mathrm{kDa}(\mathrm{O})$ and $90 \mathrm{kDa}(\boldsymbol{)})$ are indicated

iodinated A 14 insulin and $\alpha$-amino isobutyric acid were obtained from Amersham (Canada). Chemicals for polyacrylamide gel electrophoresis were obtained from Bio-Rad Laboratories (Richmond, California). All other chemicals were of reagent grade.

\section{Preparation of Hepatocytes and Plasma Membranes}

Hepatocytes were isolated from male Wistar rats (Charles River, $225-275 \mathrm{~g})$ by perfusion with collagenase $\left(500 \mathrm{mg} / 1,15 \mathrm{~min}, 37^{\circ} \mathrm{C}\right)$ according to the method of Berry and Friend [16], except that heparin $(1.5 \mathrm{IU} / \mathrm{ml})$ was added to the preperfusion buffer. The exclusion of Trypan Blue by freshly-isolated cells was over $94 \%$. The insulin stimulation of amino acid transport in the freshly isolated hepatocytes was measured by the method of Fehlmann et al. [17]. Insulin at $100 \mathrm{nmol} / 1$ was found to induce a 2 -fold increase in the uptake of $\alpha$-aminoisobutyric acid. Insulin at $85 \mathrm{nmol} / 1$ stimulated 2.5 -fold the synthesis of glycogen in cultured hepatocytes as measured by the method of Nyfler et al. [18].

A crude plasma membrane fraction was prepared from rat liver by homogenizing $1 \mathrm{~g}$ of minced tissue in $5 \mathrm{ml}$ Eagle's medium. Aliquots of $1.5 \mathrm{ml}$ of homogenate were then centrifuged for $10 \mathrm{~s}$ at $6500 \mathrm{~g}$ in an Eppendorf microcentrifuge. The supernatant was then centrifuged for $4 \mathrm{~min}$ at $6500 \mathrm{~g}$ to yield a pellet which was resuspended in $1 \mathrm{ml}$ Eagle's medium by vortexing for $30 \mathrm{~s}$ and then centrifuged for $4 \mathrm{~min}$ at $6500 \mathrm{~g}$. This crude pellet was then resuspended in Eagle's medium or binding buffer and used without further manipulation. Plasma membrane fractions from freshly-isolated hepatocytes were prepared in a similar fashion. Plasma membranes from rat adipocytes were prepared as previously described [19].

\section{Photoaffinity labeling and Scatchard analysis}

Cells $\left(1 \times 10^{9}\right.$ cells $\left./ 1\right)$ or plasma membrane fraction $(100-300 \mathrm{mg}$ protein $/ 1$ ) were incubated for $60 \mathrm{~min}$ at $18^{\circ} \mathrm{C}$ with the photoreactive insu- lin $(10-50 \mathrm{nmol} / \mathrm{l})$ in $1 \mathrm{ml}$ of Eagle's medium containing bacitracin $(0.16 \mathrm{~g} / \mathrm{l})$ with or without an excess of insulin $(10 \mu \mathrm{mol} / 1)$. Photolysis was then carried out for $20 \mathrm{~s}$ using a focussed light source from a 100-W high-pressure mercury lamp [1]. The photolabelled samples were washed in Eagle's medium and immediately solubilized in $2 \%$ sodium dodecyl sulphate containing dithiothreitol $(100 \mathrm{mmol} / 1)$. The binding of insulin with hepatic plasma membranes $(100-200 \mu \mathrm{g}$ protein $/ 0.2 \mathrm{ml}$ ) was carried out at $\mathrm{pH} 7.4$ for $20 \mathrm{~h}$ at $4{ }^{\circ} \mathrm{C}$ in $0.2 \mathrm{ml}$ Tris$\mathrm{HCl}(50 \mathrm{mmol} / \mathrm{l})$ containing $0.4 \mathrm{ng} / \mathrm{ml}$ monoiodinated A14 ${ }^{125} \mathrm{I}$-insulin $(0.4 \mu \mathrm{g} / 1)$, bovine serum albumin $0.1 \%$ and bacitracin $1.0 \mathrm{mmol} / 1$. About $2 \%$ of the ${ }^{125}$ I-insulin was degraded during binding as estimated by trichloracetic acid precipitation. Binding data were analysed by Scatchard plot using the "Ligand" programme [20]. Electrophoresis in $5-10 \%$ gradient polyacrylamide slab gels, radioautography and the calculation of apparent molecular weights were carried out as previously described [1].

\section{Results}

Complete reduction of the photolabelled insulin receptor of intact hepatocytes revealed specifically-labeled subunits of $130 \mathrm{kDa}$ and $90 \mathrm{kDa}$ and a $115-\mathrm{kDa}$ band (Fig.1). A 40-kDa band was not clearly labelled in this particular incubation but was identified more clearly in others (Fig. $2 \mathrm{a}$ and $\mathrm{b}$ ). The rôle of endogenous proteolytic activity and clostridial collagenase in the appearance of the $115-\mathrm{kDa}$ band was examined in freshly-prepared hepatic plasma membranes. The $115-\mathrm{kDa}$ band was barely detectable in hepatic plasma membranes kept on ice prior to photolabeling (Fig. 2a, Lane 2), but was increased if the plasma membranes were incubated at $37^{\circ} \mathrm{C}$ for $15 \mathrm{~min}$ (Fig. 2a, Lane 4). Treatment with clostridial collagenase further increased the appearance of this band (Fig. 2a, Lane 6). This treatment did not significantly affect the labelling of the $90-\mathrm{kDa}$ and $40-\mathrm{kDa}$ components (Fig. 2a and b). When isolated hepatocytes were cultured for $18 \mathrm{~h}$ or more, photolabelling did not reveal the 115-kDa band (Fig. 2b, Lane 2). However, treatment of these cells with the preparation of clostridial collagenase used for hepatocyte isolation induced the appearance of the $115-\mathrm{kDa}$ band (Fig. 2b, Lane 3). In contrast to this effect on hepatocytes, earlier reports have shown that the isolation of adipocytes using collagenase did not induce the labelling of a $115-\mathrm{kDa}$ band $[4,8]$. In this study we found further that treatment of adipocyte plasma membranes with collagenase similarly failed to produce a labelled $115-\mathrm{kDa}$ band despite the presence of a readily-labelled $130-\mathrm{kDa}$ subunit (Fig. 2c). There was no decrease in the overall photolabelling of the hepatic or adipocyte insulin receptor after treatment of the membranes with collagenase at the concentrations used in this study.

To determine the extent to which treatment with clostridial collagenase could increase the appearance of the $115-\mathrm{kDa}$ band we incubated freshly-prepared hepatic plasma membranes with collagenase (50 or $500 \mathrm{mg} / \mathrm{l}$ ) for increasing periods of time. After photolabelling and gel electrophoresis the labelled bands of $130,115,90$ and $40 \mathrm{kDa}$ were excised for the determination of radioactivity. The $130-\mathrm{kDa}$ subunit and $115-\mathrm{kDa}$ 


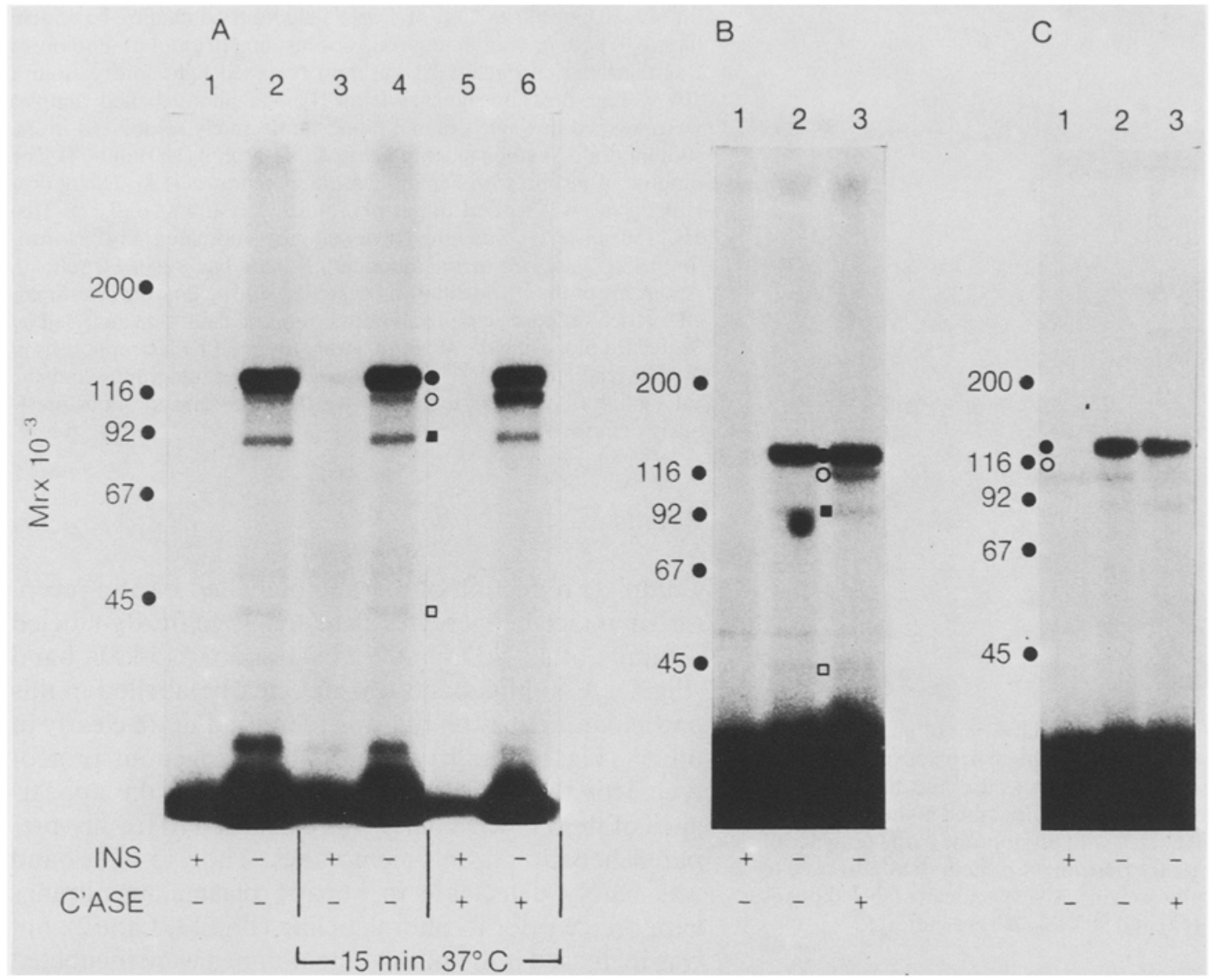

Fig. 2 A-C. Radioautograms showing the effect of endogenous protease activity and treatment with clostridial collagenase on the appearance of the $115-\mathrm{kDa}$ band in the insulin receptor of hepatic and adipose tissue. a Freshly-prepared crude hepatic plasma membranes were photolabelled as described in the text. Prior to photolabelling the plasma membranes were either kept on ice (lanes $1-2$ ), incubated for 15 min at $37^{\circ} \mathrm{C}$ (lanes 3-4), or treated with collagenase $\left(500 \mathrm{mg} / 1\right.$ ) for $15 \mathrm{~min}$ at $37^{\circ} \mathrm{C}$ (lanes 5-6). The preparation was then centrifuged for $4 \mathrm{~min}$ at $6500 \mathrm{~g}$ and the pellet resuspended in fresh Eagle's medium by vortexing for $30 \mathrm{~s}$. This procedure was repeated twice. b Freshly-isolated hepatocytes were cultured for $18 \mathrm{~h}$ and then photolabelled (Lanes 1 and 2). The 90-kDa band in Lane 2 was partially obscured by a contaminating radioactive spot. Lane 3 was obtained from cultured hepatocytes treated with collagenase as above and washed prior to photolabelling. The viability of the control or collagenase-treated cells was over $94 \%$ as assessed by the exclusion of Trypan Blue. c Adipocyte plasma membranes were prepared as outlined in the text and then photolabelled (Lanes 1 and 2). The faint band of $100 \mathrm{kDa}$ in Lane 2 was non-specific since it was also present in Lane 1 . Lane 3 was obtained from adipocyte plasma membranes treated with collagenase as above prior to photolabelling. After photolabelling, samples were analysed by gel electrophoresis as described in the text. Lanes marked INS (+) were obtained from samples incubated with photoprobe in the presence of excess insulin. Dots mark the position of protein standards used to calculate apparent molecular weights. The specifically-labeled bands of $130 \mathrm{kDa}(\bullet), 115 \mathrm{kDa}(\mathrm{O}), 90 \mathrm{kDa}(\square)$ and $40 \mathrm{kDa}(\square)$ are indicated

band together accounted for more than $85 \%$ of the total radioactivity specifically associated with the bands. In control samples kept on ice before photolabelling the ratio of radioactivity in the $115-\mathrm{kDa}$ band to that in the $130-\mathrm{kDa}$ band was 5:95. Incubation of the plasma membrane for $15-40 \mathrm{~min}$ at $37^{\circ} \mathrm{C}$ without collagenase increased this ratio to $21: 79$. Treatment with collagenase $50 \mathrm{mg} / 1$ for $40 \mathrm{~min}$, or with $500 \mathrm{mg} / 1$ for $15-40 \mathrm{~min}$, changed this ratio maximally to $36: 64$ (Fig.3). To investigate the possibility that this maximal limit resulted from inactivation of some component(s) of the clostridial collagenase during the incubation, experiments were carried out in which, after incubation for $20 \mathrm{~min}$ with up to $300 \mathrm{mg}$ collagenase per litre, a second aliquot of enzyme preparation (up to $300 \mathrm{mg} / 1$ ) was added and the incubation continued for a further $20 \mathrm{~min}$. Under these conditions the plasma membranes was exposed to up to $600 \mathrm{mg}$ collagenase per litre for $40 \mathrm{~min}$ at $37^{\circ} \mathrm{C}$. Once again the ratio of radioactivity specifically associated with the $115-\mathrm{kDa}$ band and $130-\mathrm{kDa}$ subunit remained unchanged at $36: 64 \%$.

We found that both the endogenous generation of the 115-kDa band and the effect of treatment with clostridial collagenase were $\mathrm{Ca}^{++}$dependent, inhibited completely by benzamidine $(10 \mathrm{mmol} / \mathrm{l})$ and by 3 molar equivalents of 1 antitrypsin [21], but not by soybean trypsin inhibitor (SBTI) nor by $\alpha_{2}$ macroglobulin, a specific inhibitor of collagenolytic enzymes [22]. The activity in the collagenase preparation responsible for the increased detection of the $115-\mathrm{kDa}$ band was heat-labile 


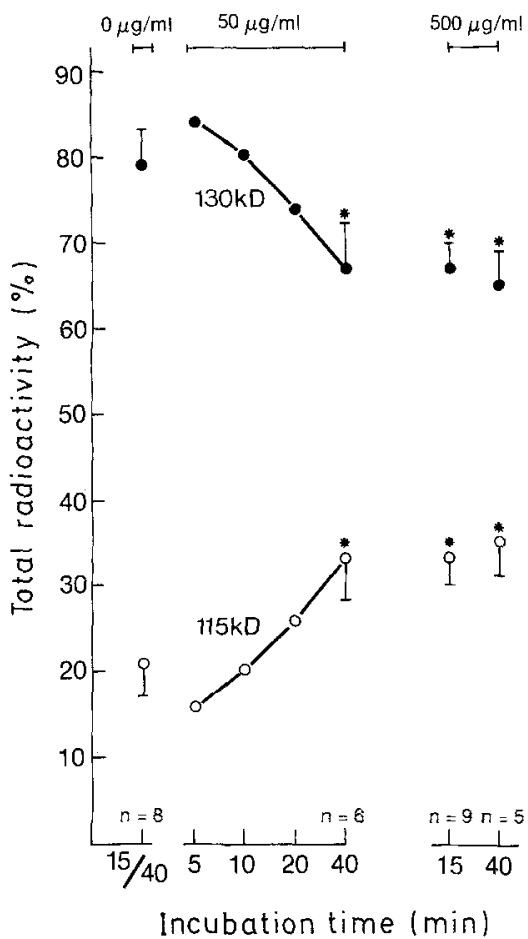

Fig. 3. The effect of collagenase concentration and duration of treatment on the limited increase in the appearance of the $115-\mathrm{kDa}$ band detected in hepatic plasma membranes. Before photolabelling, crude hepatic plasma membranes were incubated with collagenase $(0,50$ or $500 \mathrm{mg} / \mathrm{l}$ ) for the various periods of time at $37^{\circ} \mathrm{C}$. After photolabelling, the membranes were analysed by gel electrophoresis as described in the text. The specifically-labelled bands were then excised for determination of radioactivity. The specific radioactivity associated with the $130-\mathrm{kDa}$ subunit and the $115-\mathrm{kDa}$ band was then expressed as a percentage of the total radioactivity of both bands. Except where $(n)$ is indicated, the data represent the mean of three experiments. One standard deviation is indicated by the vertical bar. * indicates a significant difference from samples incubated at $37^{\circ} \mathrm{C}$ without collagenase ( $p>0.05$; one-way analysis of variance). $15 / 40$ indicates that similar results were obtained after 15 or $40 \mathrm{~min}$ of incubation

and non-dialysable. These findings demonstrated that some contaminating components (probably heat-labile proteases) in the enzyme preparation, and not the collagenolytic enzymes themselves, were responsible for inducing the increased appearance of the labelled $115-\mathrm{kDa}$ band.

It was possible that the increased electrophoretic mobility of hepatic $115-\mathrm{kDa}$ band was due to the deglycosylation of some of the $130-\mathrm{kDa}$ subunits. However, we found that treatment of the labelled receptor with neuraminidase increased the electrophoretic mobility of both bands to the same extent. This finding indicates that both were glycoproteins containing sialic acid. It also suggests that the $115-\mathrm{kDa}$ glycoprotein band in liver was distinct from the non-glycosylated $115-\mathrm{kDa}$ subunit detected in insulin receptors present in brain tissue $[23,24]$.

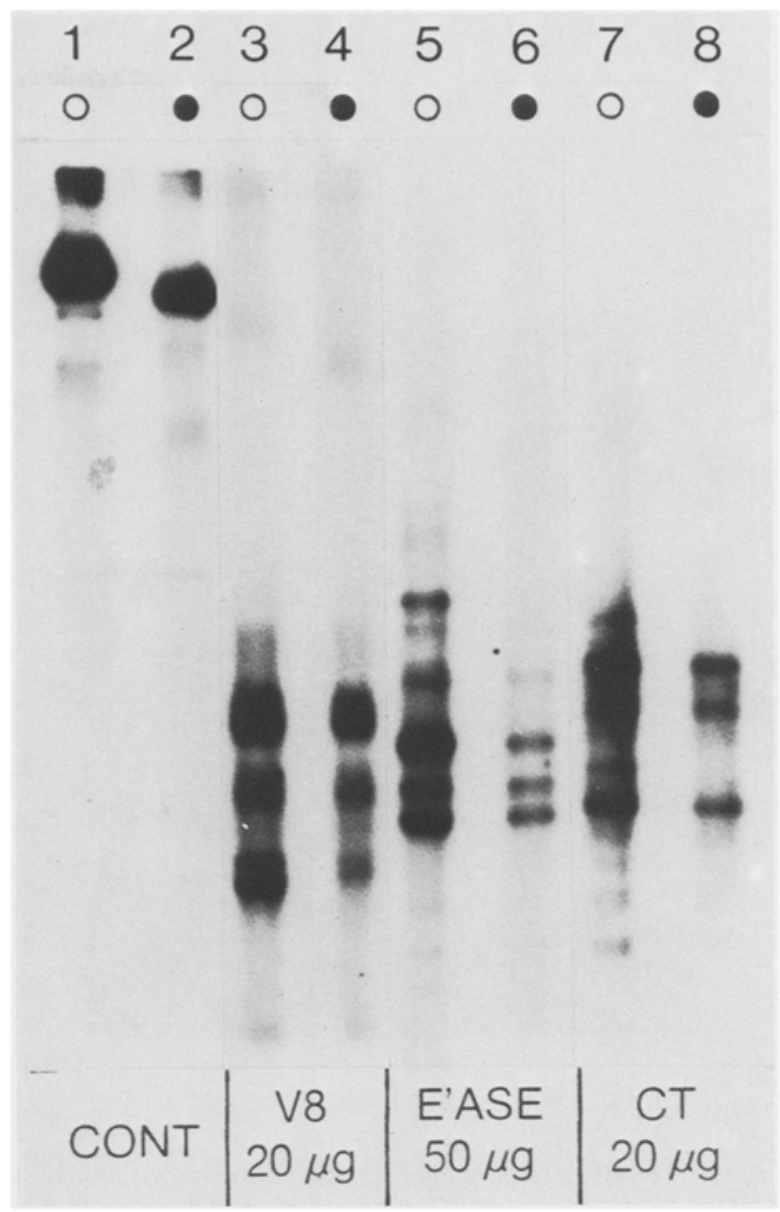

Fig.4. Radioautogram showing the result of in-gel digestion of the labelled $130-\mathrm{kDa}$ subunit and $115-\mathrm{kDa}$ band obtained from hepatic insulin receptor. Freshly-prepared hepatic plasma membranes were treated with collagenase $\left(500 \mathrm{mg} / 1,15 \mathrm{~min}, 37^{\circ} \mathrm{C}\right)$ and then photolabelled and analysed by gel electrophoresis as described in the text. The labelled $130-\mathrm{kDa}$ and $115-\mathrm{kDa}$ bands were then excised and inserted into a 10-15\% gradient slab gel for in-gel proteolysis with chymotrypsin (CT), elastase (E'ASE) and staphylococcus aureus V8 protease (V8). Lanes 1 and 2 were obtained from undigested $130-\mathrm{kDa}$ and $115-\mathrm{kDa}$ bands respectively. Lanes $3-8$ were obtained following in-gel digestion of the 130-kDa band $(O)$ and 115-kDa band $(O)$ as indicated

The possibility that the hepatic $115-\mathrm{kDa}$ band was produced by proteolytic "nicking" of the $130-\mathrm{kDa}$ subunit was examined indirectly by the in-gel digestion method of Cleveland [25]. Utilizing three different enzymes, a high degree of similarity was observed between the peptide bands generated from the $130-\mathrm{kDa}$ subunit and from the 115-kDa band (Fig. 4).

The effect of the relative abundance of the $115-\mathrm{kDa}$ band and the binding of insulin to the hepatic insulin receptor was examined in hepatic plasma membranes prepared from freshly isolated hepatocytes and hepatic membranes prepared from freshly-homogenized liver. In either case the plasma membranes were prepared using ice-cold Eagle's medium and kept on ice. The insulin receptors in these two preparations displayed marked differences in their proportions of photolabelled 130-kDa subunit and 115-kDa band (Fig. 5a). In 

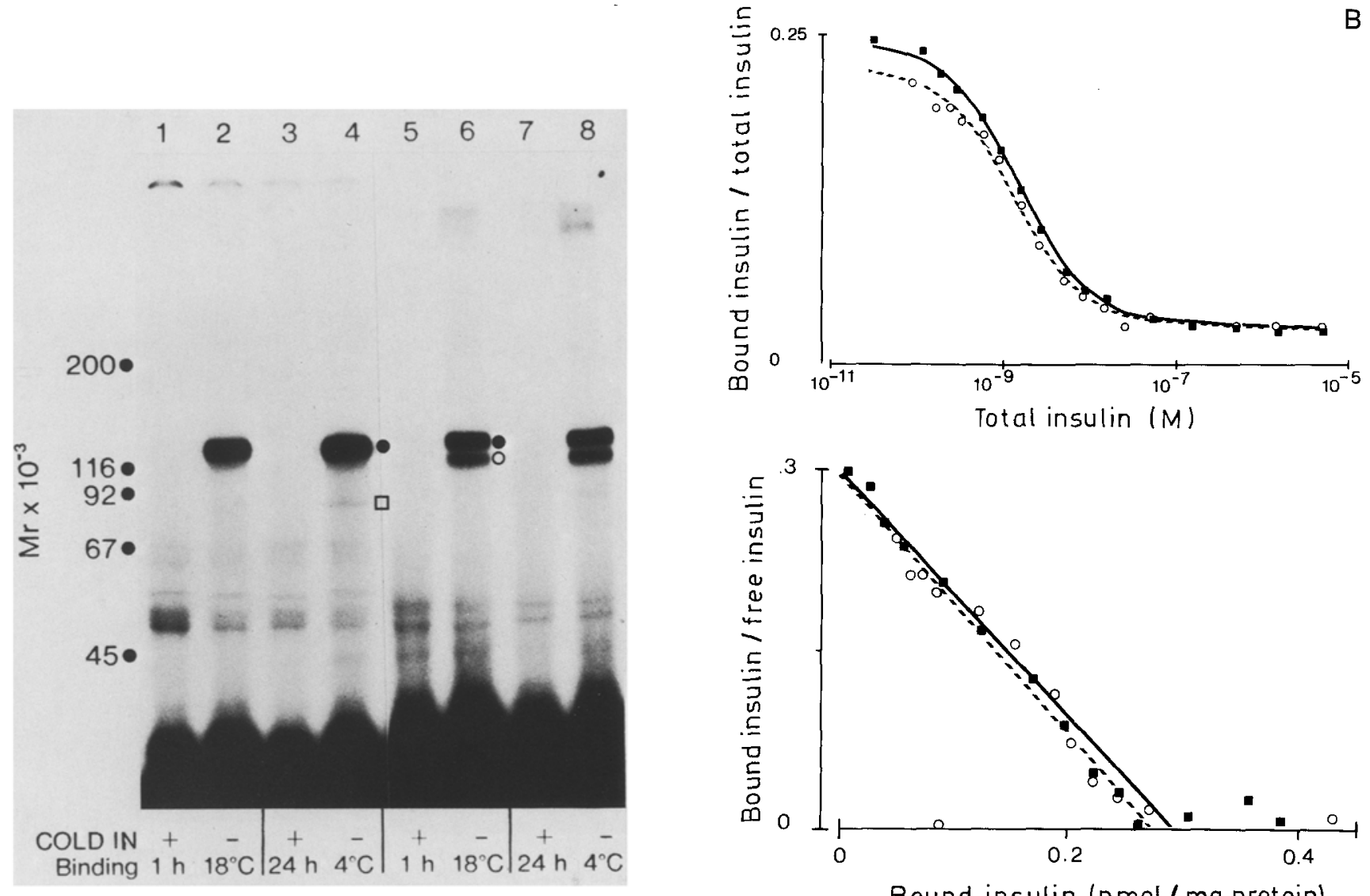

Fig.5A and B. The effect of partially degrading the hepatic $130-\mathrm{kDa}$ subunit to the $115-\mathrm{kDa}$ form on the binding of insulin to the insulin receptor. a Radioautogram showing the different amounts of $130 \mathrm{kDa}$ subunit and $115 \mathrm{kDa}$ band present in plasma membranes obtained from freshlyhomogenised liver (lanes 1-4), and from freshly isolated hepatocytes (lanes 5-8). In each case samples were incubated with the photoprobe for $1 \mathrm{~h}$ at $18^{\circ} \mathrm{C}$ (Lanes $1,2,5$ and 6) and for $24 \mathrm{~h}$ at $4{ }^{\circ} \mathrm{C}$ (Lanes 3, 4, 7 and 8 ) to determine the stability of 130-kDa subunit during the binding study. Following photolabelling, samples were analysed by gel electrophoresis as described in the text. Lanes marked COLD IN $(+)$ were obtained from samples incubated in the presence of excess insulin. Dots show the location of protein standards. The specifically-labelled bands of $130 \mathrm{kDa}(\mathbf{C})$, $115 \mathrm{kDa}(\mathrm{O})$ and $90 \mathrm{kDa}(\square)$ are shown. b Scatchard analysis of insulin binding to crude plasma membranes obtained from freshly-homogenised liver and freshly-isolated hepatocytes. Plasma membranes from each preparation were incubated with A14 monoiodoinsulin in Tris-BSA buffer, $\mathrm{pH} 7.4$ as described in the text. Top, the displacement curve obtained from both preparations assayed in duplicate is shown and is representative of the results of three separate experiments. Bottom, the Scatchard plots derived from these data. -- O --- Hepatic plasma membranes; - - hepatocyte plasma membranes

the plasma membranes prepared from hepatocytes the labelled $130-\mathrm{kDa}$ subunit and $115-\mathrm{kDa}$ band were in a ratio of $64: 36$, while in that prepared from liver the ratio was 95:5. In each preparation the relative amounts of the labelled $130-\mathrm{kDa}$ subunit and $115-\mathrm{kDa}$ band remained the same when photolabelling was carried out for either $60 \mathrm{~min}$ at $18^{\circ} \mathrm{C}$ or $24 \mathrm{~h}$ at $4{ }^{\circ} \mathrm{C}$ (Fig. $5 \mathrm{a}$ ). In both preparations Scatchard analysis demonstrated a single class of high-affinity binding sites (Fig. $5 \mathrm{~b}$ ). In plasma membranes from hepatocytes the binding association $\left(\mathrm{K}_{\mathrm{a}}\right)$ was $(1.0 \pm 0.1) \times 10^{9} \mathrm{~mole}^{-1}$, while in that from homogenized liver the $\mathrm{K}_{\mathrm{a}}$ was $\left.1.1 \pm 0.1\right) \times 10^{9}$ mole $^{-1}$ (mean $\pm S E M$ ). In the plasma membranes from hepatocytes the binding capacity $\left(R_{0}\right)$ was $0.29 \pm$ $0.01 \mathrm{nmol} / \mathrm{g}$ protein and in the preparation from homogenized liver the $R_{0}$ was $0.26 \pm 0.02 \mathrm{nmol} / \mathrm{g}$ protein. Thus, the insulin binding properties of these two plasma membrane preparations were identical.

\section{Discussion}

In this study, in addition to the expected receptor components of $130 \mathrm{kDa}, 90 \mathrm{kDa}$ and $40 \mathrm{kDa}[1-8]$, a band of $115 \mathrm{kDa}$ was detected in the insulin receptor of both intact hepatocytes and hepatic plasma membranes (Fig. 1 and 2). Respectively, the $115-\mathrm{kDa}$ band and the $130-\mathrm{kDa}$ subunit detected here are equivalent to the 120-125-kDa band and 125-135-kDa subunit reported by others $[9,10,14]$. Analysis of the peptides from the proteolytic digestion of these bands (Fig. 4) suggests that the $115-\mathrm{kDa}$ band may be derived from the $130-\mathrm{kDa}$ subunit. This supports the suggestion by others that the appearance of the 115-kDa band is the result of proteolytic "nicking" of the $130-\mathrm{kDa}$ subunit $[9,10]$. Additional evidence for this process is provided by the demonstration that labelled $130-\mathrm{kDa}$ subunit can be converted to a $115-\mathrm{kDa}$ form in hepatic plasma mem- 
branes [14]. Our results also confirm the suggestion by others that treatment of hepatic plasma membranes with clostridial collagenase [10], and endogenous proteolytic activity in hepatic plasma membranes [9] can degrade the $130-\mathrm{kDa}$ subunit to a $115-\mathrm{kDa}$ form. We demonstrated further that collagenase treatment of intact hepatocytes also degrades the $130-\mathrm{kDa}$ subunit to a $115-\mathrm{kDa}$ form. Our results also showed that this effect of clostridial collagenase was due to contaminating protease activity in the enzyme preparation rather than the collagenolytic enzymes themselves.

However, the effect of collagenase preparation on the hepatic insulin receptor had a limited, maximal extent, indicated by the inability of exhaustive treatment with the enzyme preparation to degrade all of the $130-\mathrm{kDa}$ subunit. Thus, over $60 \%$ of the $130-\mathrm{kDa}$ subunits were resistant to degradation to a $115-\mathrm{kDa}$ form despite a 10-fold increase in the amount of collagenase used (Fig. 3). This was not due to the inactivation of the contaminating proteolytic activity, since identical results were obtained when aliquots of fresh collagenase were added for a second incubation. One possible explanation for this observation is that hepatic plasma membranes contain two classes of insulin receptor, the $130-\mathrm{kDa}$ subunit being susceptible to proteolytic nicking in one but not in the other. It is noteworthy that insulin receptors in hepatic plasma membranes could also be separated into two populations based on their hydrophobic/hydrophilic properties [11] or on their binding of insulin analogues $[12,13]$. However, the relationship between our findings and these other observations is uncertain.

In contrast, adipocyte plasma membranes seem to contain only one class of insulin receptor. Thus, photolabelling of adipocytes isolated using the same collagenase preparation and photoprobe failed to reveal a $115-\mathrm{kDa}$ band [8]. In addition, the treatment of adipocyte plasma membranes with this preparation was unable to generate the appearance of the $115-\mathrm{kDa}$ band (Fig. 2c). Similarly, other investigators have observed that the $130-\mathrm{kDa}$ subunit in insulin receptor purified from IM-9 lymphocytes or placental membranes was totally insensitive to degradation by preparations of clostridial collagenase [26]. Consequently, in contrast to the insulin receptor of hepatic tissue, that of adipose tissue, placenta and IM-9 lymphocytes appears to be of a class whose $130-\mathrm{kDa}$ subunit is insensitive to the proteolytic activity present in preparations of collagenase. These possible tissue differences in the proteolytic sensitivity of the 130-kDa subunit are in keeping with the findings by other investigators that there are structural differences between the insulin receptors in hepatic, adipose and placental tissue [27-30]. The different proteolytic sensitivities may reflect alterations in the orientation of the receptor within the plasma membranes or in the organisation of subunits within the receptor.

The existence of two different receptor classes may have a role in the regulation and function of the hepatic insulin receptor. It has been reported by others that a limited proportion of the $130-\mathrm{kDa}$ subunit in the insulin receptors of both adipose [31, 32] and hepatic [9, 10, 14] tissue may undergo conversion in the plasma membranes to a $115-\mathrm{kDa}$ form. In adipocytes this process is associated with internalisation [31,32]. Studies of receptor recycling in hepatocytes have also demonstrated that while the $130-\mathrm{kDa}$ subunit was recycled back to the plasma membranes, the $115-\mathrm{kDa}$ form was not [10]. Therefore, the two classes of the insulin receptor may enable intracellular organelles to sort out those receptors destined for degradation from those destined for recycling [33].

In this study, we have observed that insulin binding by hepatic insulin receptors was not affected by the relative proportion of the 130-kDa and 115-kDa forms of the 130-kDa subunit (Fig. 5). This suggests that conversion of the $130-\mathrm{kDa}$ subunit to the $115-\mathrm{kDa}$ form involves a region of the subunit not involved in insulin binding. Thus, these two forms of the insulin binding subunit do not represent high- and low-affinity conformations of the insulin receptor as has been previously suggested [14]. This earlier study was based upon the increased appearance of the $115-\mathrm{kDa}$ form of the $130-\mathrm{kDa}$ subunit during the dissociation of insulin from the receptor, rather than upon analysis of binding characteristics. In view of our present findings this increased appearance of the 115-kDa form was likely to be due to the endogenous proteolytic degradation of the $130-\mathrm{kDa}$ subunit during the period of dissociation. Our results also support the findings by others that there is a single class of high-affinity binding sites on the insulin receptor [34-38].

In summary, photoaffinity labelling of insulin receptors present in hepatic plasma membranes demonstrated that endogenous protease activity and proteolytic activity contaminating commercial preparations of clostridial collagenase were able to degrade the $130-\mathrm{kDa}$ subunit of the insulin receptor to a $115-\mathrm{kDa}$ form. However, such degradation was restricted to only a limited proportion of the insulin receptors, raising the possibility of the presence of two classes of insulin receptor in hepatic plasma membranes. One class of receptors is characterised by a $130-\mathrm{kDa}$ subunit which can be proteolytically converted to a $115-\mathrm{kDa}$ form. The other class is characterised by receptors with a $130-\mathrm{kDa}$ subunit resistant to this effect. The degradation of the $130-\mathrm{kDa}$ subunit did not alter the binding characteristics of the hepatic insulin receptor which exhibited a single class of high affinity sites.

Acknowledgements. We thank Drs. E. Helmerhorst and Y. Kwok for reading and commenting on this manuscript. We also thank Mrs. C. Hirstwood and Mrs. T. Tallerico-Melnyk for preparing adipocytes and adipocyte plasma membranes, Mrs. H.Hsu for technical assistance in preparing the B29-MABI photoprobe and Miss K. Kokolic for preparing cultured hepatocytes. F. Haynes holds a Commonwealth Scholarship for Doctoral studies in Canada. This study was supported by MRC and C. H. Best Foundation. 


\section{References}

1. Yip CC, Moule ML, Yeung CWT(1982) Subunit structure of insulin receptor of rat adipocytes as demonstrated by photoaffinity labelling. Biochemistry 21:2940-2945

2. Jacobs S, Hazum E, Cuatrecasas $P(1980)$ The subunit structure of rat liver insulin receptor. J Biol Chem 255: 6937-6940

3. Fujita-Yamaguchi Y (1984) Characterization of purified insulin receptor subunits. J Biol Chem 259: 1206-1211

4. Massague J, Pilch PF, Czech MP (1981) A unique proteolytic cleavage site on the $B$ subunit of the insulin receptor. J Biol Chem 256:3182-3190

5. Ullrich A, Bell JR, Chen EY, Herrera R, Petruzzelli LM, Dull TJ, Gray A, Coussens L, Liao Y-C, Tsubokawa M, Mason A, Seeburg PH, Grunfeld C, Rosen OM, Ramachandran J (1985) Human insulin receptor and its relationship to the tyrosine kinase family of oncogenes. Nature 313: 756-761

6. Rosen OM, Herrera R, Olowe Y, Petruzzelli LM, Cobb MH (1983) Phosphorylation activates the insulin receptor tyrosine protein kinase. Proc Natl Acad Sci USA 80: 3237-3240

7. Brossette N, Van Obberghen E, Fehlmann M (1984) Interaction between insulin receptors and major histocompatibility complex antigens in mouse liver membranes. Diabetologia 27:74-76

8. Yip CC, Moule ML (1983) Structure of the insulin receptor of rat adipocytes: The three interconvertible redox forms. Diabetes 32: $760-767$

9. Fehlmann M, Le Marchand-Brustel Y, Van Obberghen E, Brandenburg D, Freychet $P(1982)$ Photoaffinity labelling of the insulin receptor in intact rat hepatocytes, mouse soleus muscle, and cultured human lymphocytes. Diabetologia 23 : 440-444

10. Fehlmann $M$, Carpenter J, Van Obberghen E, Freychet $P$, Thamm P, Saunders D, Brandenburg D, Orci L (1982) Internalized insulin receptors are recycled to the cell surface in rat hepatocytes. Proc Natl Acad Sci USA 79: 5921-5925

11. Meyer HE, Kopp F, Bucher U, Passlack W, Sessiz HT, Reinauer H (1983) Separation of insulin receptor proteins in the Triton X114 two-phase system. Evidence for two distinct receptor populations. 2nd International Symposium on Insulin Receptors, Rome, Italy, p 12 (Abstract)

12. Al-Attas O, Taylor R, Whittaker I, Alberti KGMM (1983) Characterization of cooperative and non-cooperative insulin binding sites in rat liver membranes. 2nd International Symposium on Insulin Receptors, Rome, Italy, p19 (Abstract)

13. De Meyts P, Fehlmann M (1981) Physiological implication of negative cooperativity and heterogenity in rat liver insulin receptors. Diabetes (Suppl 1) 30: 207 (Abstract)

14. Donner DB, Yonkers K (1983) Hormone-induced conformational changes in the hepatic insulin receptor. $\mathbf{J}$ Biol Chem 258: 9413-9418

15. Yip CC, Yeung CWT, Moule ML (1980) Photoaffinity labeling of insulin receptor proteins of liver plasma membrane preparations. Biochemistry 19:70-76

16. Berry MD, Friend DS (1964) High-yield preparation of isolated rat liver parenchymal cells. A biochemical and fine structural study. J Cell Biol 239: 375-380

17. Fehlmann M, LeCam A, Freychet P (1979) Insulin and glucagon stimulation of amino acid transport in isolated rat hepatocytes. $J$ Biol Chem 254: 10431-10437

18. Nyfeler F, Fasel P, Walter P (1981) Short term stimulation of net glucogen production by insulin in rat hepatocytes. Biochim Biophys Acta $675: 17-23$

19. McKeel D, Jarett L (1970) Preparation and characterization of a plasma membrane fraction from isolated fat cells. J Cell Biol 44: $417-432$

20. Munson PJ, Rodbard D (1980) Ligand: A versatile computerized approach for characterization of ligand-binding systems. Anal Biochem 107: 220-239

21. Wooley DE, Roberts DR, Evanson JM (1975) Inhibition of human collagenase activity by a small molecular weight serum protein. Biochem Biophys Res Comm 66: 747-754
22. Werb Z, Burleigh MC, Barrett AJ, Starkey PM (1974) The interaction of $\alpha_{2}$ macroglobulin with proteinases. Binding and inhibition of mammalian collagenase and other metal proteinases. Biochem J 139: 359-368

23. Heidenreich KA, Zahaniser NR, Berhanu P, Brandenburg D, Olefsky JM (1983) Structural differences between insulin receptors in the brain and in peripheral target tissues. J Biol Chem 258: $8527-8530$.

24. Yip CC, Moule ML, Yeung CWT (1980) Characterisation of insulin receptor subunits in brain and other tissues by photoaffinity labeling. Biochem Biophys Res Comm 96: 1671-1678

25. Cleveland DW, Fischer SG, Kirschner MW, Laemmli UK (1977) Peptide mapping by limited proteolysis in sodium dodecyl sulfate and analysis by gel electrophoresis. J Biol Chem 252: 1102-1106

26. Roth RA, Mesirow ML, Cassell DJ (1983) Preferential degradation of the B subunit of purified insulin receptor. J Biol Chem 258 : $14456-14460$

27. Lyen KR, Smith RM, Jarett L (1983) Differences in the ability of anti-insulin antibody to aggregate monomeric ferritin-insulin occupied receptor sites on liver and adipocyte plasma membranes. Diabetes 32: 648-653

28. Jarett L, Smith RO (1983) Partial disruption of naturally occurring groups of insulin receptors on adipocyte plasma membranes by dithiothreitol and $\mathrm{N}$-ethylmaleimide: The role of disulfide bonds. Proc Natl Acad Sci USA 80: 1023-1027

29. Massague J, Czech MP (1982) Role of disulfides in the subunit structure of the insulin receptor. Reduction of class I disulfides does not impair transmembrane signalling. I Biol Chem 257: 6729-6738

30. Podlecki DA, Frank BH, Kao H, Horikoshi G, Freidenberg S, Marshall T, Ciaraldi T, Olefsky JM (1983) Characterization of the receptor binding properties of monoiodoinsulin isomers and the identification of different insulin properties of different insulin receptor specificities in hepatic and extrahepatic tissue. Diabetes 32: 697-704

31. Berhanu P, Olefsky JM, Tsai P, Thamm P, Saunders D, Brandenburg D (1982) Internalization and molecular processing of insulin receptors in isolated rat adipocytes. Proc Natl Acad Sci USA 79: 4069-4073

32. Heidenreich KA, Berhanu P, Brandenburg D, Olefsky JM (1983) Degradation of insulin receptors in rat adipocytes. Diabetes 32 : $1001-1009$

33. Krupp M, Lane MD (1981) On the mechanism of ligand-induced down-regulation of insulin receptor level in the liver cell. J Biol Chem 256: 1689-1694

34. Donner DB (1980) Regulation of insulin binding to isolated hepatocytes: Correction for bound hormone fragments linearizes Scatchard plots. Proc Natl Acad Sci USA 77: 3176-3180

35. Kahn CR, Freychet P, Roth J (1974) Quantitative aspects of the insulin-receptor interaction in liver plasma membranes. J Biol Chem 249: 2249-2257

36. Gammeltoft S, Kristensen LO, Sestoft L (1978) Insulin receptors in isolated rat hepatocytes. J Biol Chem 253: 8406-8413

37. Caro JF, Amatruda JM (1980) Functional relationships between insulin binding, action and degradation. J Biol Chem 255: 10052-10055

38. Kohanski RA, Lane MD (1983) Binding of insulin to solubilized insulin receptor from human placenta. J Biol Chem 258: $7460-7468$

Received: 12 April 1985

and in revised form: 22 August 1985

Dr. C.C.Yip

Banting and Best Department of Medical Research

University of Toronto

112 College Street

Toronto, Ontario, M5G 1 L6

Canada 